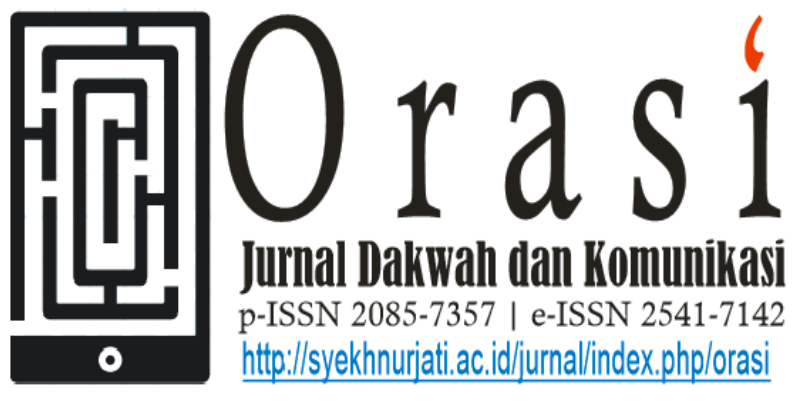

Volume 9 No. 1, PP 39 - 52; Juli 2018

\title{
STRATEGI RADIO PUBLIK LOKAL DALAM UPAYA MEMPEROLEH MINAT PENDENGAR
}

\author{
Nur Latifah', Muzaki2(*) \\ Mahasiswa Jurusan Komunikasi dan Penyiaran Islam ${ }^{1}$ \\ Dosen Fakultas Ushuluddin Adab dan Dakwah ${ }^{2}$ \\ IAIN Syekh Nurjati Cirebon \\ nur.latifah@syekhnurjati.ac.id ${ }^{1}$, muzaki@syekhnurjati.ac.id $^{(*)}$
}

\begin{abstract}
ABSTRAK
Media massa saat ini bersaing untuk mendapatkan perhatian khalayak, Televisi, Surat Kabar atau pun Radio. Saat ini Radio sudah jarang untuk di dengar oleh khalayak. Terkadang radio menjadi media yang tertinggal untuk mendapatkan sejumlah informasi dan hiburan. Sehingga radio ditinggalkan oleh para pendengarnya. Oleh karena itu agar radio dapat menarik para pendengarnya, terutama radio di Cirebon. Maka Radio Maritim Rassonia yang bernaung di bawah Pemerintah Daerah. Dalam penelitian ini difokuskan untuk mendeskripsikan upaya Radio Maritim dalam memperoleh minat untuk program MAMIKU (Maritim Minta Kidung) dengan Strategi perencanaan, Strategi Produksi dan Pembelian program, serta Pengawasan dan Evaluasi program. Untuk strategi program MAMIKU (Maritim Minta Kidung) adalah perencanaan program, dimana Radio Maritim ini memiliki jadwal MAMIKU pada jam 14. 00-17. 00 dengan segmentasi anak muda untuk mendengarkan musik terbaru dan informasi terkini yang disiarkan. Metode yang digunakan dalam penelitian ini yaitu kualitatif deskriptif dengan teknik pengumpulan data berupa Wawancara, Observasi penelitian dan Dokumentasi. Berdasarkan penelitian, dapat disimpulkan bahwa strategi perencanaan program MAMIKU memiliki cara agar pendengar musik dan informasi ini dapat di dengar oleh khalayak maka dibentuklah wadah untuk berkumpul yang dinamakan komunitas Soda Mania (Sobat Muda Maritim Rassonia) sehingga program MAMIKU tetap berjalan dan eksis di kalangan anak muda. Dalam produksinya program MAMIKU mempunyai perannya masing-masing dalam menjalankan tugasnya, sehingga MAMIKU bisa menjadikan sumber informasi dan musik terkini yang di minati anak muda. Tentunya pengawasan dan evaluasi diperlukan agar program MAMIKU tetap berjalan dengan baik, terpantau dari banyaknya telepon, sms dan facebook akan terlihat berapa banyak pendengar yang request lagu terbaru yang ada di Playlist program $M A M I K U$.
\end{abstract}

Kata Kunci: radio publik, minat, pendengar, strategi, kidung 


\section{PENDAHULUAN}

Radio publik lokal didirikan bertujuan untuk menyeimbangkan antara radio swasta dan radio komunitas dalam segi informasi, pendidikan, maupun hiburan. Radio Maritim Rasonia pada saat itu mendirikan radio siaran khusus informasi dan hiburan. Dan Radio Maritim berada di bawah naungan Badan Kerja sama Unsur Maritim (Baksumar) yang berlokasi di Pelabuhan Cirebon pada tahun 1965. Pada saat itu program siaran yang disajikan hanya informasi tentang kedatangan kapal barang ke Pelabuhan Cirebon maupun yang pergi serta hiburan bagi Anak Buah Kapal (ABK) yang bersandar di Pelabuhan. Namun pada saat SK Menteri penerangan RI mengharuskan bahwa semua radio siaran swasta bergabung dalam wadah Persatuan Radio Siaran Swasta Nasional Indonesia (PRSSNI).

Radio Maritim Rassonia bergabung dengan PRSSNI pada tahun 1972 dengan nomor keanggotaan 077-1/1972. Pada tahun 1980 Radio Maritim pindah lokasi menempati gedung sendiri di Jalan. Sudarsono 20, sebuah stasiun radio yang desainnya sesuai dengan persyaratan yang berlaku bagi radio siaran swasta. Menyadari bahwa radio maritim sudah menjadi bagian dari masyarakat untuk menjaga citranya mulaiah diadakan pembenahan khususnya dalam 3 hal yaitu manusia, bahan dan teknologi. Radio Maritim Rassonia memiliki daya pancar yang jangkauannya luas, Kota Cirebon, Kab. Cirebon, Kab Majalengka, dan Kab. Kuningan. Radio maritim dapat mengambil jumlah pendengar dari sms masuk, telpon, social media dan grafik database pendengar. Pendengar meliputi remaja dan dewasa ,karena banyaknya program yang sesuai dengan usia atau pun lagu sesuai pilihannya.

Radio merupakan media auditif (hanya bisa di dengar) murah, merakyat, serta bisa dibawa dan dengar dimana saja. J. B. Wahyudi, mendefinisikan radio sebagai alat pemancar gelombang elektromagnetik yang membawa muatan signal suara yang di bentuk dari microphone, kemudian pancaran ini diterima system antena yang diteruskan ke pesawat penerima (radio) dan sinyal radio di ubah kembali menjadi suara atau audio loadspeaker. (Achmad Setiyaji,2015:4).

Sehingga radio siaran mempunyai ciri dan sifat yang berbeda dengan media massa lainnya. jelas berbeda dengan surat kabar yang merupakan media cetak,juga dengan film yang bersifat mekanik optic. Dengan televisi, kalaupun ada persamaannya dalam sifatnya yang elektronik, terdapat perbedaan, yakni radio sifatnya audial, utelevise audiovisual. Karena sifatnya audiotori, untuk didengarkan, lebih mudah orang 
menyampaikan pesan dalam bentuk acara yang menarik. Penyajian hal yang menarik dalam rangka penyampaian suatu pesan, karena publik sifatnya selektif. (Onong Ucriana,1991:18-19)

Menurut buku Elvinaro Ardianto (2007:125) radio siaran (Broadcasting) digunakan sebagai alat media komunikasi massa, di perkenalkan oleh Lee De Forest melalui radio siaran eksperimennya pada tahun 1916 telah menyiarkan kampanye pemilihan presiden amerika serikat antara wilson dan hughes kepada masyarakat umum,sehingga ia dianggap sebagai pelopor radio siaran, dan dijuluki the father of radio siaran atau bapak radio siaran yang juga menyiarkan berita radio siaran. Seiring berkembangnya zaman menuju zaman modern maka berkembang juga media massa pada saat ini, salah satunya media massa elektronik.

Saat ini radio sering kali tertinggal dengan media lain, ketika televisi banyak memberikan perhatian khalayak radio siaran, khalayak memperkirakan bahwa radio siaran berada diambang kematian. Radio adalah media massa elektronik tertua dan sangat luwes. Radio siaran mendapat julukan kekuatan kelima atau the fifth estate. Hal ini disebabkan radio juga dapat melakukan fungsi kontrol sosial seperti surat kabar, disamping empat fungsi lainnya yakni memberi informasi, menghibur, mendidik, dan melakukan persuasi. (Elvinaro Ardianto,2007:123).

Maka radio harus bisa bersaing dengan media lain untuk memenuhi kebutuhan pendengar. Khalayak harus mendapat alternatif siaran untuk memperoleh informasi, pendidikan dan hiburan. Dengan adanya kemajuan elektronik yang memudahkan khalayak untuk mendapatkannya secara mudah, misalnya musik dengan gadget yang ada bisa membuat masyarakat tertarik untuk mengunduh dan menikmati sajian musik setiap saat. Tak hanya gadget dari siaran televisi dengan acara musik, MP3, Itunes, dan CD. Melalui media tersebut semakin banyak khalayak yang memutar musik favoritnya. Hal ini menyebabkan radio ditinggalkan karena massanya yang sudah diikuti oleh zaman.

Adapun yang dimaksud dengan strategi program adalah perencanaan, dalam hal ini mencangkup keseluruhan penjadwalan stasiun penyiaran dan jadwal penyiaran. Sebagaimana yang telah diungkapkan Pringle Star dan rekannya bahwa " Program planning involves the development of short-, medium-, and longrange plans to permit the station to attain its programmingand financial objective" "ini berarti perencanaan program mencakup pekerjaan mempersiapkan rencana jangka pendek, menengah, dan jangka panjang yang memungkinkan stasiun penyiaran untuk mendapatkan 
tujuan program dan tujuan keuangannya. Pada stasiun radio mencakup pemilihan format dan isi program yang dapat menarik dan memuaskan kebutuhan audien yang terdapat pada suatu segmen audien berdasarkan demografi tertentu. Dan perencaan program radio juga mencakup mencari penyiar yang memiliki kepribadian dan gaya yang sesuai dengan format yang sudah dipilih stasiun bersangkutan. (Morissan,2008:274).

Daya langsung siaran radio berkaitan dengan proses penyusunan dan penyampaian pesan pada pendengarnya yang relatif cepat. Suatu pesan yang disampaikan melalui surat kabar aan membutuhkan waktu yang relatif lama. Pemberitaan dengan surat kabar harus disusun secara panjang, diset,koreksi,dicetak,angkut kepada para agen, dan disebarkan kepada para pelanggan. Sedangkan dalam siaran radio, berita sudah dikoreksi dan di cek kebenarannya serta dapat langsung dibacakan,bahkan radio siaran dapat menyiarkan suatu peristiwa yang tengah berlangsung melalui radio siaran reportase atau siaran pandangan mata. Radio siaran mempunyai kekuatan dalam memperoleh; daya tarik. Daya tarik ini di sebabkan karena adanya sifat yang serba hidup berkat tiga unsur yang ada padanya, yakni musik, kata-kata dan efek suara (Sound effect). Tulang punggung radio adalah musik.

Inilah yang dikatakan Meeske kelemahan radio, diantaranya:

a. Radio is aural only. Satu-satunya cara yang diandalkan radio untuk menyampaikan pesan adalah bunyi (sound). Radio berbeda dengan media massa televisi yag dilengkapi dengan gambar untuk membayangkan kejadian sesungguhnya, biasanya pendengar

menggunakanteaterimajinasinya sendiri.

b. Radio message are short lived. Pesan radio bersifat satu arah, sekilas, dan tidak dapat ditarik lagi begitu diudarakan. Karena itu menyampaikan pesan melalui radio bukan pekerjaan main-main. Tetapi harus dilakukan dengan hati-hati dan penuh ritanggung jawab.

c. Radio listening is prone to distraction. Radio penuh dengan gangguan. Pendengar adalah unsur terpenting dalam menikmatinya, karena jika pendengaran terganggu maka tidak ada lagi cerita dalam kehidupan radio. Selain itu juga pendengar radio biasanya tidak hanya terfokus mendengarkan, melainkan sambil melakukan pekerjaan lain. Akibatnya konsentrasi cepat terpecah.

Komunikasi Massa merupakan 
proses komunikasi yang dilakukan melalui media khalayak luas. Serta memiliki proses yang berbeda dengan komunikasi tatap muka. Karena sifat komunikasi massa yang melibatkan banyak orang, maka proses komunikasinya sangat kompleks dan rumit. Komunikasi Massa menggunakan media massa, dan komunikasi yang disampaikan kepada khalayak yang banyak, seperti rapat akbar di lapangan luas yang dihadiri ribuan,bahkan puluhan ribu orang, jika tidak menggunakan media massa, maka itu bukan komunikasi massa. Komunikasi massa menghasilkan produk berupa pesanpesan komunikasi. Dan disebarkan, didistribusikan kepada khalayak secara terus-menerus dalam jangka waktu yang tetap, misalnya harian, mingguan atau bulanan. (Burhan Bungin, 2006:71-74).

Stasiun penyiaran publik berbentuk badan hukum yang didirikan oleh Negara, bersifat independen, netrl, tidak komersial, dan berfungsi memberikan layanan untuk kepentingan masyarakat. Terdiri atas Radio Republik Indonesia (RRI) dan Televisi Republik Indonesia (TVRI) yang berada di ibu kota Negara. Indonesia membedakan antara stasiun publik dengan stasiun komunitas. Dalam pengertiannya stasiun publik dan komunitas ini masuk dalam kategori stasiun nonkomersial yang meliputi empat jenis stasiun yaitu : a) stasiun penyiaran komunitas; b) stasiun penyiaran universitas; c) stasiun penyiaran sekolah; dan d) stasiun penyiaran milik badan daerah.

Keempat stasiun penyiaran nonkomersial ini dapat di tingkatan statusnya menjadi stasiun publik bila telah memenuhi sejumlah ketentuan minimal yang ditetapkan oleh badan pengawasan stasiun publik Amerika, yaitu Corporation for Public Broadcasting (CPB) yang dibentuk pada tahun 1967 untuk mengelola seluruh stasiun penyiaran nonkomersial harus memiliki waktu siaran minimal 3000 jam per tahun, memiliki minimal 10 karyawan, memiliki anggaran operasional minimal $\$ 300.000$ dalam satu tahun, dan sebagainya. Dengan demikian, sebagian besar stasiun publik Amerika sebenarnya adalah stasiun komersial nonkomersial yang dikelola oleh masyarakat dan lembaga pendidikan.

Tujuan radio publik di antara Memberikan pelayanan informasi, pendidikan, hiburan yang sehat, control dan perekat social serta melestarikan budaya bangsa untuk kepentingan seluruh lapisan masyarakat melalui penyelenggaraan penyiaran televisi yang menjangkau seluruh wilayah Indonesia. Dan PPL Radio Maritim harus menjadi corong dan mampu untuk Program Musik.

Menurut Amirullah Strategi merupakan suatu rencana yang diutamakan untuk mencapai tujuan. Melalui strategi 
akan berorientasi ke masa yang akan datang untuk berinteraksi dengan lingkungan yang kompetitif untuk mencapai tujuan organisasi yang merefleksikan kesadaran suatu organisasi mengenai bagaimana, kapan dan dimana organisasi akan bersaing: terhadap siapa organisasi harus bersaing: apa maksud organisasi bersaing. (Amirullah, 2015:5).

Sedangkan menurut Morissan pola tanggapan organisasi terhadap lingkungannya sepanjang waktu. Dimana setiap organisasi selalu mempunyai Strategi walaupun tidak pernah secara eksplisit dirumuskan. Serta menghubungkan sumber daya manusia dan berbagai sumber daya lainnya dengan tantangan dan risiko yang harus dihadapi dari lingkungan di luar perusahaan (Morissan,2011:144).

Pada pembahasan tinjauan strategi, peneliti akan berusaha untuk menjelaskan berbagai macam strategi untuk memperkaya keilmuan meliputi, strategi program, strategi komunikasi, strategi pemasaran, serta strategi Penyiaran.

Dalam mencapai suatu keberhasilan dalam radio, tentunya memiliki wilayah kajian. Departemen program dan manajer program stasiun penyiaran memiliki kedudukan yang sangat strategis dalam menunjang keberhasilan stasiun penyiaran. Tentunya strategi program ditinjau dari aspek manajemen atau sering disebut dengan manajemen strategis (management strategic) dan terdiri dari (Morissan,2008:273) :

1) Perencanaan program

2) Produksi dan pembelian program

3) Eksekusi program

4) Pengawasan dan evaluasi program

Berkembang dari pemikiran tersebut para pendiri mempunyai gagasan/ide untuk mendirikan Radio siaran khusus informasi dan hiburan. Terbentur dengan perijinan yang ada pada waktu itu, melalui perjuangan yang panjang akhirnya mengudara Stasiun Radio swasta dengan nama Radio Maritim dibawah naungan Badan Kerja Sama unsure Mariti (Baksumar) yang berlokasi dalam pelabuhan Cirebon pada tahun 1965.

Program siarannya hanya informasi tentang kedatangan kapal-kapal barang ke pelabuhan Cirebon maupun yang pergi serta hiuran untuk Anak Buah Kapal (ABK) yang bersandar. Adapun jam siarannya mulai jam 08.00-12.00 dan 16.00-20.00 wib pada frekuwensi SW.

Suguhan Program dan seiring berkembangnya jaman, tentu program yang ada di radio tak mau kalah dalam pencapaian usahanya. Maka Program yang di suguhkan di Radio Maritim Rassonia ini memiliki cara tersendiri, agar pendengar tetap setia mendengarkan radio tentunya 
dengan program yang unggul. Serta pembawaan terhadap penyiar yang akrab dengan sapaan SodaMania. Berikut Program Radio Maritim Rassonia Setiap Hari Indonesia.

Hiburan

Segala bentuk siaran yang bertujuan untuk menghibur audien dalam bentuk musik, lagu, cerita, dan permainan. Radio Maritim Rassonia memberikan program unggulan salah satunya hiburan dan musik memiliki presentasi $50 \%$ yang di minati remaja masa kini.

Informasi

Jika dilihat manusia memiliki sifat rasa ingin tahu dalam hal apa pun, salah satunya informasi. Informasi teraktual dapat di temukan di radio dan televisi yang di sesuaikan dengan kebutuhan audien.Segala jenis siaran yang tujuannya untuk memberikan tambahan pengetahuan (informasi) kepada khalayak audien.Tentunya Radio Maritim Rassonia mempunyai program Maritim Indonesia yang menyajikan Informasi hingga $20 \%$ yang unik dan menarik untuk pendengar. Serta Program Letter E yang memberikan informasi seputar wilayah III Cirebon dan tips menarik yang bisa di dapat oleh pendengar.

Pendidikan

Program yang memiliki edukasi di radio maritim salah satunya Relay dari NHK radio dimana ini menyajikan pembelajaran bahasa jepang pada pukul 21.00-22.00. Pembelajaran ini di laksanakan pada malam hari dimana banyak kosa kata bahasa jepang yang dipelajari tujuan agar mengetahui cara memaparkan bahasa jepang dengan baik. Ini efektif karena malam hari suasana akan lebih tenang dan santai ketika mendengarkan Relay NHK radio ini dan mudah di jangkau melalui udara tanpa harus mempelajari di tempat kursus bahasa Jepang.

Layanan Masyarakat

Tagline Setiap Hari Indonesia, tentunya Radio Maritim memberikan layanan kepada masyarakat baik informasi, musik, lagu, pendidikan dengan program yang tersedia.Agar pendengar bisa mengikuti sajian program yang telah di rancang, tentun y a sesuai dengan target pendengar.

Jika melihat para DJ dan fomat top 40 menyelamatkan radio pada tahun 1950an. Dan mengubah musik popular dan industry rekaman untuk selamanya.Namun remaja menyukai suara yang baru dan menjadi dasar bagi para remaja untuk membentuk subkulturnya sendiri. Dan juga sebagai basis ledakan industri musik rekaman. (Stanley 2012:274).

Dalam mendengarkan radio pasti lagu yang di cari dan ingin didengarkan oleh audien. Maka program MAMIKU radio maritim memberikan suguhan untuk 
pedengarnya, tentunya dengan lagunya Genre, Pop, Rock and Rol dan sebagainya.Siaran musik pada radio maritim sebanyak $60 \%$ Pendengar MAMIKU berbagai macam pendengar baik laki-laki maupun perempuan.

\section{METODOLOGI PENELITIAN}

Penelitian tentang "Strategi Radio Publik Lokal dalam Memperoleh Minat Pendengar".Digunakan dengan metode penelitian kualitatif. Beberapa alasan menggunakan pendekatan kualitatif adalah metode ini dapat digunakan untuk memberikan suatu strategi dalam pembuatan program untuk memperoleh minat pendengar dengan tujuan yang telah diharapkan. Dengan digunakannya metode kualitatif, maka data yang didapat lebih lengkap, lebih mendalam, kredibel, dan bermakna sehingga tujuan penelitian dapat dicapai.Dalam buku Rulam Ahmadi bahwa penelitian kualitatif adalah penelitian yang menggunakan latar alamiah, dengan maksud menafsirkan fenomena yang terjadi dan melibatkan berbagai metode yang ada. (Rulam Ahmadi,2014:14).

Teknis analisis data kualitatif berkaitan erat dengan metode pengumpulan data, yaitu observasi dan wawancara ataupun Focus Group Discussion. Bahkan terkadang suatu teori yang dipilih berkaitan erat secara teknis dengan metode pengumpulan data dan metode analisis data.Dengan demikian pengumpulan data dilakukan (wawancara dan observasi) melalui tradisi teknik analisis data tersebut. Peneliti seharusnya memilih teknik analisis data apa yang di gunakan (karena jumlahnya sama ) sesuai dengan kecocokan dalam pengumpulan dengan objek penelitian. (Burhan Bungin,2007:79).

Analisis data merupakan proses sistematis pencarian dan pengaturan transkripsi wawancara, catatan lapangan dan materi-materi lain yang telah dikumpulkan untuk meningkatkan pengalaman penulis sendiri mengenai materi tersebut. Dan untuk memungkinkan penulis dalam menyajikan apa yang sudah ditemukan dengan orang lain. Analisis melibatkan pekerjaan dengan data,penyusunan,dan pemecahannya ke dalam unit-unit yang dapat di tangani, perangkumannya, pencarian pola-pola dan penemuan apa yang penting dan apa yang perlu dipelajari dan pembuatan keputusan apa yang akan anda katakan pada orang lain. (Emzir,2010:85-86)

\section{HASIL DAN PEMBAHASAN}

Tentunya Radio Maritim Mendirikan suatu program sesuai dengan kebutuhan masyarakat dan melihat di era yang sudah mulai maju. Dengan segmentasi anak muda salah satunya 
program MAMIKU (Maritim Minta Kidung) dimana Kidung adalah sebutan untuk lagu. Setiap pendengar yang ingin lagunya di putar bisa gunakan slogannya "Maritim Minta Kidung". Ada juga planning khusus untuk anak muda kecuali rekues malam hari kalangan orang tua. Dan planning kedua untuk remaja dan orang tua, dimana industri radio sekarang lebih variatif, Kalau tidak ada radio tentu tidak adanya program siaran sehingga dalam membuat satu acara atau satu program bisa di ikuti oleh pendengar . Dalam program MAMIKU tentunya didukung oleh iklan yang mengikuti program siaran tersebut. Karena radio pasti memiliki iklan yang mendukung aktifitas dari program tersebut, Maka para klien yang memasang iklan di radio maritim pun ikut mendengarkan apakah iklan ini disiarkan atau tidak, karena jika terjadi tidak adanya pemutaran iklan maka para klien otomatis akan memberhentikan iklan yang mereka masukan ke dalam program MAMIKU. Sehingga MAMIKU ini bisa dikatakan bahwa perencanaannya bisa memberikan efek positif kepada para pendengar setianya, sehingga tetap eksis hingga sekarang. Dengan sajian lagu dan informasi yang dibawakan oleh penyiar.

\section{Membuat Perencanaan}

Seperti yang dikemukakan oleh prigle star dan rekannya mengenai Perencanaan program ini mencakup pekerjaan dalam jangka panjang, menengah, dan jangka panjang dimaksudkan agar program memiliki penjadwalan yang sesuai.

$$
\text { Dapat dikatakan syane bahwa }
$$
"Program MAMIKU (Maritim Minta Kidung) yang merupakan acara musik dan informasi di Radio Maritim ini memiliki jadwal siaran jam 14.00-17.00 dan target segmentasi acara ini mencakup anak sekolah dan mereka sudah pulang kerumah dan para pekerja yang sudah menyelesaikan pekerjaannya dari pagi sampai sore, sehingga mereka mendengarkan musik melalui radio sesuai dengan pilihan. ( Wawancara 24 April 2016)."

Untuk menarik para pendengar tentunya program MAMIKU ini membuka kesempatan untuk para pendengar berinteraksi dengan penyiar melalui telepon dan sms sehingga memudahkan mereka untuk meminta lagu sesuai dengan perasaan mereka, titip salam dan memiliki teman baru dalam program tersebut, dan tak hanya musik, informasi menarik pun ada sesuai tema. Sehingga para pendengar mempunyai respon yang baik dan simpati terhadap program MAMIKU.

\section{Tujuan Program}

Dalam suatu perusahaan tentunya memiliki tujuan agar perusahaan atau organisasi dapat berjalan sesuai dengan keinginan yang dicapai. Dalam radio pasti 
memiliki tujuan agar program yang dicanagkan bisa berjalan dengan baik, karena pada dasarnya radio memilii strategi agar radio ini tetap berkembang, bertahan dan eksis dengan program yang dicanangkan.

Dapat dikatakan oleh rimo "Maka Radio Maritim mempunyai tujuan tersendiri dalam memberikan suguhan hiburan dan program serta berita yang mengedukasi masyarakat. agar radio Maritim mampu bersaing di dunia bisnis jasa penyiaran dan berkembang, ditengah persaingan yang semakin ketat. Radio Maritim didirikan sesuai falsafah UUD, sehingga dapat mencerdaskan kehidupan bang melalui media penyiaran. Tentunya dengan suguhan hiburan dan program serta berita yang mengedukasi masyarakat.agar radio Maritim mampu bersaing idunia bisnis jasa penyiaran dan berkembang, ditengah persaingan yang semakin ketat. Banyak hal yang mempengaruhi dalam mempertahankan eksistensi radio Maritim, diantaranya kondisi mikro, diperlukan dana yang tidak kecil untuk membiayai ManusianyaProgramnya dan Teknologinya serta faktor kejenuhan".

\section{Faktor Program}

Dewasan y a Radio merupakan teman aktifitas bagi kaum laki-laki dan perempuan, anak remaja, Dewasa bahkan orang tua. Maka dalam penyampaian
Program pun MAMIKU mempunyai waktu para pendengar untuk meminta lagu pilihannya melalui telepon dan berinteraksi dengan penyiarnya sehingga memiliki feedback tersendiri bagi pendengar.Bagi pendengar berbincang dengan penyiar itu merupakan suatu kebangaan karena dengan begitu MAMIKU memiliki daya tarik yang unik. Penyampain informasi juga bisa di lakukan sesuai dengan tema yang ada.

\section{Pengawasan dan Evaluasi Program} MAMIKU (Maritim Minta Kidung) Radio Maritim Rassonia

Untuk mengambil simpati pendengar program MAMIKU maka radio maritim tetap mengawasi dan mengevaluasi pada jam siaran. Karena dengan langkah tersebut program MAMIKU akan terus aktif dan tetap berjalan dengan adanya pendengar setia radio maritim. Dengan cara membuka telepon, sms dan sosial media yang pastinya pendengar akan selalu aktif dalam mendengarkan radio. Selain via telepon atau sms juga bisa diimbangi lagi apakah program ini tetap berjalan atau berhenti, karena itu semua pasti memerlukan pendengar yang aktif dan respon yang besar. Ternyata program ini di dukung penuh oleh pendengar dan terus berjalan hingga sekarang.

Dapat dikatakan Syane "Dalam pengawasan dan evaluasi tentu nya dalam program ini memiliki iklan dan 
semua radio khusus nya Radio Maritim memutar iklan klien yang sudah mempercayakan kepada Radio Maritim. Karena dengan adanya iklan otomatis klien akan mendengarkan radio dimana mereka memasang iklan. Radio publik lokal untuk dikonsumsi oleh publik agar lebih legalitas lagi. Dan untuk karyawan Radio Maritim juga pasti mengawasi dan hanya memberikan warning dan jadwal dibawakan penyiar dalam program MAMIKU dari jam 14.00-17.00 untuk closing. Seluruh karyawan dan penyiar akan terus aktif dalam memantau Program MAMIKU dimana ini program terbaik dan banyak pendengarnya. Serta adanya pengawasan klien terhadap iklan yang dipasang di program MAMIKU karena sesuai jika di putar pada jam siar program MAMIKU. (Wawancara 3 April 2016 jam 10.00 di radio maritime). Dengan demikian, maka proses perencanaan Program MAMIKU (Maritim Minta Kidung) tentunya harus memiliki kekuatan diantaranya kompetensi khusus yang ada di dalam program MAMIKU (Maritim Minta Kidung) sudah memiliki keunggulan dimana memiliki strategi bahwa program MAMIKU ini berhasil mendapatkan minat pendengar dari Genre lagu yang terbaru serta diadakannya komunitas SodaMania sebagai pendengar setia pada program MAMIKU. Di samping itu Program MAMIKU juga memiliki peluang dimana hasil iklan yang di putar saat Program MAMIKU dari bisnis yang ada sehingga terbantunya program tersebut. Tentunya musik yang ada saat ini sudah terbantu dengan adanya Music Director juga mengawasi juga mengawasi lagu-lagu yang diputar untuk mengetahui sudah sesuai format program MAMIKU atau melanggar format program MAMIKU.

\section{Analisis Peluang}

Seiring dengan berjalannya waktu, Radio Maritim pasti akan memberikan pelayanan yang terbaik untuk para pendengarnya. Yang merupakan radio lokal berada di Kota Cirebon. Apalagi di lihat dari sekarang sudah banyak radio yang memunculkan program lebih terbaru dan menarik untuk di minati pendengar.

Dalam hal ini juga pesaing terus berjalan sampai kapan pun. Maka radio maritim menyajikan program terbaiknya, terlebih melihat musik yang sekarang sudah banyak didapatkan, tapi berbeda dengan radio maritim yang memasukan program ini ke dalam waktu yang tepat dimana anak muda sekarang lebih menyukai musik dan suguhan informasi menarik. Sehingga tak ada bosannya mereka dalam mendengarkan radio maritim.

\section{Analisis Kompetitif}

Dengan adanya program MAMIKU (Maritim Minta Kidung) tentu nya radio maritime tak tertinggal dengan 
radio lain. Suguhan musik dan informasi menarik bisa didapatkan, terlebih ada nya komunitas SodaMania yang selalu mendukung dalam program MAMIKU, dan MAMIKU juga memiliki keunggulan dibanding program yang lain, sebagai berikut:

a. Program MAMIKU merupakan program yang banyak diminati anak muda jaman sekarang, dilihat dari jadwal dan waktu siar tepat pada saat anak sekolah pulang, Karyawan yang sedang beraktifitas sambil mendengarkan radio sehingga dapat membangkitkan semangat mereka dalam bekerja. Dan mendapatkan informasi terbaru dan Update.

b. Tayang pada setiap hari, karena sesuai dengan tagline yang ada program ini setiap hari di siarkan agar pendengar bisa menikmati musik terbaru, yang diinginkan sesuai dengan segmen yang berlaku

\section{SIMPULAN DAN SARAN}

\section{Simpulan}

Berdasarkan hasil analisis data terhadap hasil penelitian, maka peneliti menyimpulkan, yaitu :

1) Perencanaan Program

Program MAMIKU memutar musik pilihan sesuai dengan Genre nya dan Lagu- lagu terbaru dari musisi-musisi indonesia, Sehingga pendengar bisa mengetahui mana lagu-lagu terbaru baik indonesia atau mancanegara. Selain menikmati lagu- lagu pendengar juga bisa mendengarkan iklan dan informasi yang disajikan oleh penyiar. Khusus program direction hanya memberikan warning dan schedule dan membawakan acara MAMIKU dari jam 14.00-17.00 WIB, serta titip salam dan putar iklan dr klien. dan Program MAMIKU menarik anak remaja setelah pulang sekolah dan melakukan aktifitas dengan mendengarkan musik dan mendapatkan teman baru yang mereka tak kenal sebelum nya, karena MAMIKU ini memiliki silahturahmi terhadap pendengar setia nya untuk kumpul bersama teman baru dan penyiar ini, maka strategi ini yang menjadikan MAMIKU menjadi pusat untuk mendapatkan simpati pendengar. terlebih tak hanya berbincang via udara dengan penyiar dalam membicarakan informasi, tetapi juga di kemas agar program tersebut terus berjalan seiring berkembangnya jaman.

2) Produksi Program

Dalam pelaksanaan produksi nya tentu membutuhkan Sumber Daya Manusia (SDM) agar berjalan dengan baik, Direktur utama, administrasi, penyiar, reporter,music director, programmer, traffic radio. Mereka semua memiliki peran nya masing-masing dalam menjalankan tugasnya, agar radio maritim 
tetap eksis dengan program unggulan.dan tetap diminati oleh masyarakat yang lambat laun menghilangkan rasa untuk mendengarkan radio. Padahal radio merupakan sumber informasi yang terupdate sejak jaman dulu hingga sekarang.

3) Pengawasan dan Evaluasi

Pengawasan dan Evaluasi tentunya terus di pantau, terlebih program MAMIKU yang tayang setiap hari dengan memiliki ratting yang baik di kalangan anak muda. Dengan adanya sms, via telepon, sosial media bisa dilihat seberapa banyak pendengar yang aktif dan pasif, artinya pasif jika pendengar itu-itu saja dan yang aktif merupakan pendengar yang baru bergabung, dan dilihat dari ada nya Komunitas SodaMania dan memiliki kekeluargaan yang bisa membangkitkan program MAMIKU yang didominasi oleh anak muda.

\section{Saran}

Berdasarkan hasil penelitian yang telah dilakukan, penulis melihat bahwa radio lokal salah satu nya radio maritim telah mencapai simpati pendengar dalam program MAMIKU. Dan penulis memiliki rekomendasi dalam merekomendasikan, sebagai berikut:

a) Radio Maritim Rassonia pada program MAMIKU (Maritim Minta Kidung) lebih bisa mempersiapkan nya lebih baik lagi dari materi yang sudah ditentukan dan tak hanya lagu saja tetapi informasi dan kuis bisa di siarkan dan bisa menambah ratting dan semakin banyak nya pendengar.

b) Dalam penyiar nya juga harus bisa mengimbangi waktu jadwal dalam siaran, agar sesuai dengan skrip yang ada dan mempunyai waktu yang matang untuk materi yang akan di sampaikan kepada audiens.

c) Dan untuk program MAMIKU harus lebih di fokuskan pada musik yang terkini artinya musik terbaru bukan pop Indonesia, karena pop Indonesia memiliki jadwal siar yang sudah ditentukan.

\section{DAFTAR PUSTAKA}

Setiyaji,A, dkk. 2015. Radio The Untold Stories. Bandung: Simbiosa Rekatama Media

Uchjana Onong,1990. Radio Siaran Teori dan Praktek. Bandung: Mandar Maju

Elvinaro Ardianto (2007:125)

Ardianto,E, dkk. 2007.komunikasi massa suatu pengantar edisi rivisi. Bandung: Simbiosa Rekatama Media

Morissan. 2011. Manajemen Media Penyiaran Strategi Mengelola Radio dan Televisi. Jakarta: Prenada Media Group 
radiomaritimcirebon.blogspot.co.id/p/abou t-us_22.html

Bungin Burhan. 2007. Penelitian Kualitatif

. Jakarta: Prenada Media Grup

Emzir. 2010. Metodologi Penelitian

Kualitatif Analisis

Data. Jakarta: $\quad$ PT

RajaGrafindo Persada

Olii Helena. 2009. Reportase Radio.

Jakarta: PT Indeks

Sumadiria Haris.2006. Bahasa Jurnalistik.

Bandung: Simbiosa Rekatama

Media

Ahmadi Rulam. 2014.Metodelogi

Penelitian Kualitatif. Ar-Ruz

media. Yogyakarta 